\title{
Dexamethasone increases production of C-type natriuretic peptide in the sheep brain
}

\author{
Michele O Wilson', Bryony A McNeill2, Graham K Barrell1, Timothy C R Prickett³ \\ and Eric A Espiner ${ }^{3}$
}

${ }^{1}$ Faculty of Agriculture and Life Sciences, Lincoln University, Christchurch, New Zealand 2Faculty of Health, School of Medicine, Deakin University, Geelong, Victoria, Australia

3Department of Medicine, University of Otago, Christchurch, New Zealand

\begin{abstract}
Although C-type natriuretic peptide (CNP) has high abundance in brain tissues and cerebrospinal fluid (CSF), the source and possible factors regulating its secretion within the central nervous system (CNS) are unknown. Here we report the dynamic effects of a single IV bolus of dexamethasone or saline solution on plasma, CSF, CNS and pituitary tissue content of CNP products in adult sheep, along with changes in CNP gene expression in selected tissues. Both CNP and NTproCNP (the amino-terminal product of proCNP) in plasma and CSF showed dose-responsive increases lasting 12-16 $\mathrm{h}$ after dexamethasone, whereas other natriuretic peptides were unaffected. CNS tissue concentrations of CNP and NTproCNP were increased by dexamethasone in all of the 12 regions examined. Abundance was highest in limbic tissues, pons and medulla oblongata. Relative to controls, CNP gene expression (NPPC) was upregulated by dexamethasone in 5 of 7 brain tissues examined. Patterns of responses differed in pituitary tissue. Whereas the abundance of CNP in both lobes of the pituitary gland greatly exceeded that of brain tissues, neither CNP nor NTproCNP concentration was affected by dexamethasone, despite an increase in NPPC expression. This is the first report of enhanced production and secretion of CNP in brain tissues in response to a corticosteroid. Activation of CNP secretion within CNS tissues by dexamethasone, not exhibited by other natriuretic peptides, suggests an important role for CNP in settings of acute stress. Differential findings in pituitary tissues likely relate to altered processing of proCNP storage and secretion.
\end{abstract}

Correspondence should be addressed to M Wilson Email michele.wilson@lincolnuni. ac.nz

\section{Introduction}

C-type natriuretic peptide (CNP), a paracrine growth factor that regulates cell proliferation and maturation, is widely expressed along with its receptor (NPR-2) throughout the brain and spinal cord in mammals (Komatsu et al. 1991, Langub et al. 1995, Herman et al. 1996) including primates (Abdelalim \& Tooyama 2011). In contrast to other natriuretic peptides, concentrations of products of

Key Words
CNP
- NTproCNP
natriuretic peptide gene
expression
- cerebrospinal fluid
- pituitary
- glucocorticoid

Journal of Endocrinology (2017) 235, 15-25
CNP gene expression (CNP and amino-terminal proCNP, NTproCNP) in cerebrospinal fluid (CSF) greatly exceed those in the systemic circulation (Schouten et al. 2011, Wilson et al. 2015) and presumably reflect the high CNP abundance relative to other natriuretic peptides identified in brain tissues (Pemberton et al. 2002). Although the functional role of CNP in nervous tissues is unclear,

Published by Bioscientifica Ltd 
in vitro evidence shows that CNP stimulates neural growth and connectivity (Zhao \& Ma 2009) and neuroplasticity in hippocampal tissues (Decker et al. 2010). Changes in CNP gene expression in the perinatal and later periods of brain maturation (Müller et al. 2009) further suggest that CNP in brain tissues is subject to regulation but putative secretagogues have yet to be identified.

In the course of study of the regulation of CNP products in CSF in conscious sheep, we determined that dexamethasone (which suppresses plasma levels of CNP and NTproCNP when chronically administered to growing lambs (Prickett et al. 2009) or children (Prickett et al. 2012a)) conversely, abruptly increases concentrations of these peptides in CSF and plasma after an IV bolus injection. This novel observation has initiated a series of studies aimed to determine the temporal sequence and dose responsivity of CNP peptides in plasma and CSF to stimulation by dexamethasone and to identify the sites in the central nervous system (CNS) targeted by this glucocorticoid. Mindful of the well-recognised and profound effects of glucocorticoids on brain function (Wolkowitz et al. 2009), the focus of these studies has been the brain and nearby organs. Based on the initial observations of CNP responses in CSF, we hypothesised that: (i) the increases in CSF concentrations of CNP would be dose dependent and differ from the dynamic changes exhibited in plasma; and (ii) the increases in CSF concentration would be associated with corresponding increases in brain tissue abundance of $\mathrm{CNP}$ as well as increased CNP gene expression. Because concentrations of CNP in CNS tissues greatly exceed those of other natriuretic peptides in several species (including human (Minamino et al. 1991) porcine (Ueda et al. 1991) and ovine tissues (Pemberton et al. 2002)) we further postulated that among the family of natriuretic peptides, the response would be specific to CNP products.

\section{Materials and methods}

\section{Animal procedures}

All procedures involving animals were conducted at Lincoln University and carried out in accordance with the Animal Welfare Act 1999 (New Zealand) and were approved by the Lincoln University Animal Ethics Committee.

\section{Responses of CNP peptides in plasma and CSF to graded doses of dexamethasone (Study 1) We} first determined the dose response of peripheral venous plasma and cisternal CSF concentrations of CNP peptides to dexamethasone in chronically cannulated conscious sheep (Study 1). Eight healthy yearling Coopworth ewes (average live weight $42 \mathrm{~kg}$, 9-14 months old) were housed indoors for 1 week prior to study and fed concentrated lucerne pellets (SealesWinslow, Ashburton, New Zealand) and lucerne chaff at 09:00h every day at maintenance nutritional level, with water provided ad libitum. This feeding regime was continued for the duration of the study. One day before cannulation, sheep were fasted for $24 \mathrm{~h}$ and water withheld overnight. Initially CSF samples were collected from 2 of the sheep using cannulae that were placed into the cervical epidural space while the sheep were anaesthetised. Thereafter, with the need for improved cannula patency, all CSF samples from other sheep were collected from the cisterna magna via an indwelling cannula (Wilson \& Barrell 2015). For samples collected from the cisterna magna, $0.5 \mathrm{~mL}$ of CSF (which occupied the dead space in the cannula) was withdrawn under aseptic conditions using a $3 \mathrm{~mL}$ disposable syringe and discarded. At each sampling time point, $1.0-1.2 \mathrm{~mL}$ of CSF was withdrawn and transferred immediately to a polycarbonate tube on ice, then stored at $-20^{\circ} \mathrm{C}$ until assayed. Blood samples were obtained as described previously (Wilson et al. 2015) and were collected on the same occasions as the CSF samples. Dose response studies commenced at least 2 days after cannulation, and continued over a study period of 6 days. Dosing comprised a single IV bolus injection of dexamethasone sodium phosphate in aqueous solution (Dexa 0.2, PhoenixPharm Distributors Ltd, Auckland, New Zealand) at $0.025,0.063,0.125$ and $0.25 \mathrm{mg}$ dexamethasone/ $\mathrm{kg}$ live weight, or saline solution $(0.9 \% \mathrm{w} / \mathrm{v})$ that was delivered according to a balanced incomplete block design. This ensured that 4 different individuals were allocated to each dose of dexamethasone. The sampling was conducted immediately prior to administration of dexamethasone or saline solution, and at 4, 8, 12 and $16 \mathrm{~h}$ post administration for measurement of $\mathrm{CNP}$ and NTproCNP. To assess the glucocorticoid activity of these treatments, plasma glucose concentration was measured before and at $8 \mathrm{~h}$ post injection (dexamethasone or saline) as shown in Supplementary Fig. 1 (see section on supplementary data given at the end of this article). Plasma glucose concentration was measured by the hexokinase method using an automated analyser (Abbott c8000 Clinical Chemistry Analyzer, Abbott Diagnostics Inc., IL, USA) by Canterbury Health Laboratories, Christchurch, New Zealand. (c) 2017 Society for Endocrinology Printed in Great Britain
Published by Bioscientifica Ltd 
Responses of brain, pituitary and spinal cord levels of CNP peptides to dexamethasone (Study 2) In this study, 14 healthy Texel-Romney wethers (average live weight $77 \mathrm{~kg}, 2$ years old) were sampled as described above except that CSF samples were obtained under light anaesthesia (as previously described (Wilson et al. 2015)) and blood samples were collected (Wilson et al. 2015) immediately prior to a single IV bolus of dexamethasone containing $0.25 \mathrm{mg} / \mathrm{kg}$ live weight $(n=7)$, or saline (control, $n=7$ ), and again at $8 \mathrm{~h}$ post injection. At that point, sheep were individually killed by captive bolt and exsanguinated. The brain and pituitary gland were rapidly removed, and approximately $0.5 \mathrm{~g}$ of selected tissues from 14 sites were excised and instantly placed in liquid nitrogen. Specific zones sampled were the anterior pituitary gland, posterior pituitary gland, olfactory bulb, septum, thalamus, hypothalamus, mammillary body, hippocampus, occipital cortex, pineal gland, cerebellum, pons, medulla oblongata and cervical spinal cord. The frozen samples were stored on dry ice until they were transferred to a $-80^{\circ} \mathrm{C}$ freezer within $2-3 \mathrm{~h}$.

\section{Measurement of peptide concentration and gene expression}

Samples of frozen brain and pituitary tissue (mean $70 \pm 10 \mathrm{mg}$ ) were finely diced on a chilled melamine chopping board, weighed and gently boiled for $5 \mathrm{~min}$ in $10 \mathrm{~mL}$ distilled water containing $10 \mu \mathrm{L}$ Triton X-100. After boiling, the tissue suspension was cooled on ice, and $610 \mu \mathrm{L}$ of glacial acetic acid was added. The tissue suspension was homogenised $(3 \times 20 \mathrm{~s}$ bursts at $400 \mathrm{~Hz})$ using an Ultra-Turrax homogeniser (IKA-Labortechnik, Staufen, Germany). The tissue homogenates were then centrifuged $\left(3000 \mathrm{~g}, 4^{\circ} \mathrm{C}, 30 \mathrm{~min}\right)$, and processed thereafter in an identical manner to the CSF and plasma samples.

Hormone assays Hormones levels in CSF, plasma, brain and pituitary tissue were measured by radioimmunoassay after extraction using solid-phase cartridges (Sep Pak, Waters Corp., Milford, MA, USA). All samples from an individual animal were processed in duplicate in a single assay. CNP and NTproCNP were assayed as previously described (Wilson et al. 2015) and tissue concentrations were calculated from wet weight of tissue homogenised, assay buffer reconstitution volume and radioimmunoassay result. The ratio of NTproCNP to CNP (NTproCNP:CNP) was calculated from molar concentrations of the respective peptides in each sample. Atrial natriuretic peptide (ANP) concentration was measured as previously reported (Yandle et al. 1986) except: $50 \mu \mathrm{L}$ standard/sample was pre-incubated with $50 \mu \mathrm{L}$ of primary rabbit antiserum diluted to $1: 12,500$ for $24 \mathrm{~h}$ at $4^{\circ} \mathrm{C}$, to which $50 \mu \mathrm{L}$ of iodinated ANP was added $(2500 \mathrm{cpm} / 50 \mu \mathrm{L})$. Following a second incubation period, bound and free-labelled antigens were separated by the addition of $500 \mu \mathrm{L}$ of solid-phase secondary antibody $5 \%$ v/v Donkey anti-Rabbit Sac-cell (IDS Ltd, UK) diluted in assay buffer containing $2 \%$ polyethylene glycol. After 30 min incubation at room temperature, tubes were centrifuged for $10 \mathrm{~min}$, and radioactivity of the pellet was counted following aspiration of the supernatant. B-type natriuretic peptide (BNP) concentration was measured as previously described (Pemberton et al. 1997) except: $50 \mu \mathrm{L}$ standard/sample was pre-incubated for $24 \mathrm{~h}$ at $4^{\circ} \mathrm{C}$ with $50 \mu \mathrm{L}$ of primary rabbit antiserum, to which $50 \mu \mathrm{L}$ of iodinated BNP was added $(5000 \mathrm{cpm} / 50 \mu \mathrm{L})$. After a second incubation period, bound and free-labelled antigens were separated in a similar manner as the ANP protocol, except the assay was incubated for $30 \mathrm{~min}$ in an ice bath. The detection limit (pmol/L) for each assay was: 7.3 for ANP, 4.9 for BNP, 0.6 for CNP and 1.9 for NTproCNP. Intraand interassay coefficients of variation, respectively, were $7.8 \%(21-100 \mathrm{pmol} / \mathrm{L})$ and $10.4 \%$ (at $86 \mathrm{pmol} / \mathrm{L}$ ) for ANP, 9.9\% (4-20 pmol/L) and $15 \%$ (at $23.6 \mathrm{pmol} / \mathrm{L}$ ) for BNP, 6.3 and $7.9 \%$ at $9 \mathrm{pmol} / \mathrm{L}$ for $\mathrm{CNP}$ and 7.4 and $11.4 \%$ at $64 \mathrm{pmol} / \mathrm{L}$ for NTproCNP.

Quantitative real-time PCR Total RNA was extracted from approximately $40 \mathrm{mg}$ of tissue using the ReliaPrep RNA Tissue Miniprep System (Promega), according to the manufacturer's instructions. RNA purity was determined using a NanoDrop ND-1000 spectrophotometer (Thermo Fisher Scientific). cDNA was synthesised from $1 \mu \mathrm{g}$ of RNA template using an iScript cDNA synthesis kit (Bio-Rad Laboratories). Quantitative real-time PCR was performed using iQ SYBR green supermix (Bio-Rad Laboratories) and specific primers for ovine NPPA (Forward: CCT CCG AGA TCT GTC CTC CT; Reverse: CTT CGA TAC CGG AAG CTG TTG), NPPB (Forward: GCT GCT AGG ATG TCG TTC CC; Reverse: TCC AAC AGC TCC TGT AAC CCA), NPPC (Forward: GGT CAG AAG GGC GAC AAG A; Reverse: TGT ATT TGC GCG CGT TGG G), NPR1 (Forward: CCC TAT CAG CAG AGA GCA CG; Reverse: CAC CGA TGG TCT CCA CCT TG), NPR2 (Forward: TGC CCT CTA TGC CAA GAA GC; Reverse: GTA GAA AGG CCC ACT GCG AA), and NPR3 (Forward: CAC CCA GGA GGT 
TAT TGG TGA; Reverse: AAG GAG AGC TGT TCG TGT GCT) on a Stratagene MX3000p thermal cycler (Agilent Technologies). Gene expression was normalised to cDNA concentration, quantified using a Quant-iT OliGreen ssDNA assay kit (Thermo Fisher Scientific). To determine relative gene expression, mean $\mathrm{Ct}$ values were power transformed from their logarithmic format, and divided by sample cDNA concentration.

\section{Statistical analyses}

Changes in CNP and NTproCNP concentration in CSF, plasma and CNS tissue in response to saline or dexamethasone administration were analysed separately. In Study 1, a repeated measures ANOVA was used to compare area under the curve for the logged $\left(\log _{10}\right.$ here and in all cases thereafter) data and logged glucose concentration using Genstat Version 16 (VSN International Ltd., Hemel Hempstead, UK). Data from one sheep were excluded when pregnancy became apparent at the time of sample collection. In Study 2, a repeated measures ANOVA was used to compare logged concentrations of the various peptides in CSF, plasma, and CNS tissues in response to dexamethasone or saline solution, as well as the ratio of CNP:NTproCNP concentration in CNS tissues which was calculated for each sheep. Least significant differences were used to identify differences in CNP and NTproCNP concentration between treatment groups in specific CNS tissues. The relation between peptide concentration in tissue (logged) and the percentage difference in peptide concentration after dexamethasone was determined using linear regression analysis in GraphPad Prism version 6.01 for Windows (GraphPad Software, www.graphpad. com). Gene expression levels of NPPA, NPPB, NPPC, NPR1, NPR2 and NPR3 were compared separately using a repeated measures ANOVA in GenStat Version 16 (VSN International Ltd., Hemel Hempstead, UK) using logged data, and least significant differences were used to identify differences between saline- and dexamethasone-treated sheep for each tissue.

\section{Results}

All studies were accomplished as planned, and data collection was complete for Study 1. In Study 2, CSF samples were collected from 13 of 14 sheep at baseline, and from 10 of 14 sheep following treatment. No adverse events were noted in any animal during either study, nor were any signs of infection evident in cannulated animals.

\section{Dose responses to dexamethasone (Study 1)}

On the control day (saline injection), plasma and CSF concentration of both CNP and NTproCNP were stable during the $16 \mathrm{~h}$ period of sampling. As expected, mean concentrations of CNP and NTproCNP in CSF were higher than those in plasma $(3.32 \pm 0.14$ vs $0.94 \pm 0.02 \mathrm{pmol} / \mathrm{L}$; $817 \pm 24$ vs $47.7 \pm 1.3 \mathrm{pmol} / \mathrm{L}$, respectively, $P<0.001$ for both). There was no significant association between time-matched plasma and CSF concentrations for either peptide. Serial changes in CSF and plasma levels evoked by a range of doses of dexamethasone are shown in Fig. 1. Dose-dependent increases in both CNP peptides were observed within $4 \mathrm{~h}$ in plasma and somewhat later in CSF, although the magnitude and duration of responses differed in the two circulations. Overall, relative responses of plasma CNP and NTproCNP concentration to the highest dose of dexamethasone (8-fold and 6-fold increase, respectively) exceeded those in CSF (3.3-fold and 1.5-fold, respectively). In CSF both the onset and the offset of responses were delayed relative to those observed in plasma. Further, time to peak CSF concentrations of NTproCNP (Cmax, 16h) was delayed compared with that of CNP (Cmax 8-12h) and the NTproCNP concentration in CSF remained above pre-injection levels $16 \mathrm{~h}$ after dexamethasone administration in 3 of the 4 studies. Whereas a significant increase above control levels of plasma CNP and NTproCNP concentration was generated by the two lowest doses of dexamethasone (0.025 and $0.063 \mathrm{mg} / \mathrm{kg}, P<0.05$ ), these doses failed to raise levels of these peptides in CSF. All doses of dexamethasone used here elevated glucose levels in plasma sampled $8 \mathrm{~h}$ after administration $(P<0.05$, Supplementary Fig. 1$)$ where concentrations had increased from $4.18 \pm 0.08 \mathrm{mmol} / \mathrm{L}$ (mean plasma glucose concentration of all sheep at baseline, $n=24$ ) to between $5.98 \pm 0.11 \mathrm{mmol} / \mathrm{L}$ (lowest dose) and $7.28 \pm 0.77 \mathrm{mmol} / \mathrm{L}$ (highest dose).

\section{CNS and pituitary tissue responses to dexamethasone (Study 2)}

To ensure that responses in CSF and systemic concentrations of CNP products on the day of tissue collection were comparable to those observed in the dose-response study, both peptides were measured in plasma (at 2 hourly intervals over $8 \mathrm{~h}$ ) and CSF (preinjection and at $8 \mathrm{~h}$ after treatment). Concentrations of both peptides prior to injection were similar in saline- and dexamethasone-treated sheep and did not change significantly after saline injection in the $8 \mathrm{~h}$

Published by Bioscientifica Ltd. 
- $0.25 \mathrm{mg} / \mathrm{kg} \backslash 0.025 \mathrm{mg} / \mathrm{kg}$

A $0.125 \mathrm{mg} / \mathrm{kg} \bullet 0 \mathrm{mg} / \mathrm{kg}$ (saline)

- $0.063 \mathrm{mg} / \mathrm{kg}$

A

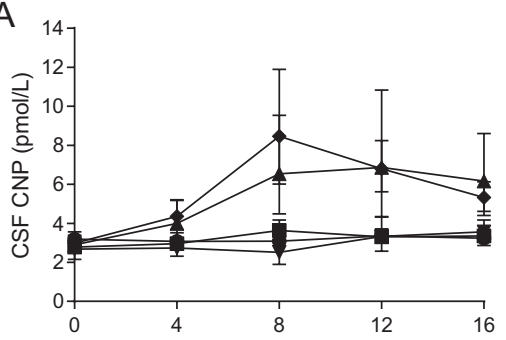

C

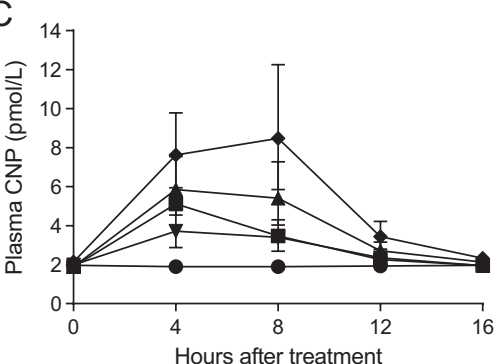

B

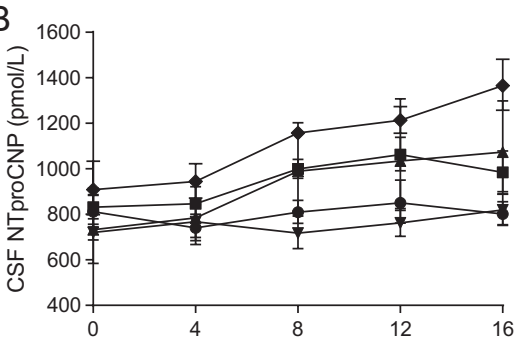

D

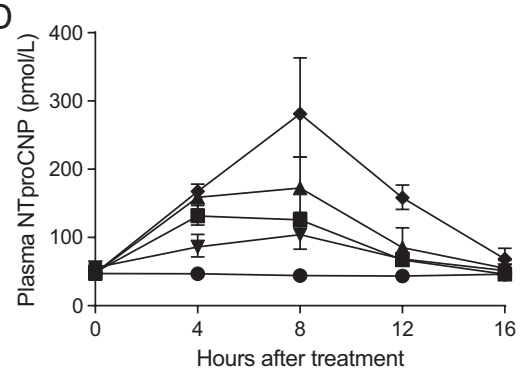

Figure 1

Mean CNP (left) and NTproCNP (right)

concentration in CSF ( $\mathrm{A}$ and $\mathrm{B}$ ) and plasma ( $\mathrm{C}$ and D) of sheep following different doses of dexamethasone: 0 (saline), $0.025,0.063,0.125$ and $0.25 \mathrm{mg} / \mathrm{kg}$ live weight. Data are presented as geometric means. $n=8$ (saline) and $n=4$ per dexamethasone dose level. period prior to tissue collection (Fig. 2). Again, as in Study 1, significant increases of CNP and NTproCNP concentration in both plasma and CSF were recorded following IV dexamethasone $(0.25 \mathrm{mg} / \mathrm{kg})$.

Across the wide range of neural tissues examined, both CNP and NTproCNP were detected in all tissue extracts. As shown in Fig. 3A, in control sheep, concentrations of CNP in the brain were highest in limbic tissues (thalamus, hypothalamus and mammillary body), medulla oblongata and pons. Low abundance was observed in the pineal gland, olfactory bulb and occipital cortex. In contrast, CNP concentrations were much higher in the anterior pituitary $(28.2 \pm 3.5 \mathrm{pmol} / \mathrm{g})$ and posterior pituitary $(15.7 \pm 4.5 \mathrm{pmol} / \mathrm{g})$ lobes (Fig. 3C). Excepting pituitary tissue, concentrations of NTproCNP (Fig. 3B and D) in tissues from salineinjected (control) sheep were almost 10-fold higher $(8.3 \pm 0.7)$ than those of CNP. Dexamethasone increased concentrations of both peptides in most tissues examined (Fig. 3A and B). Compared with controls,
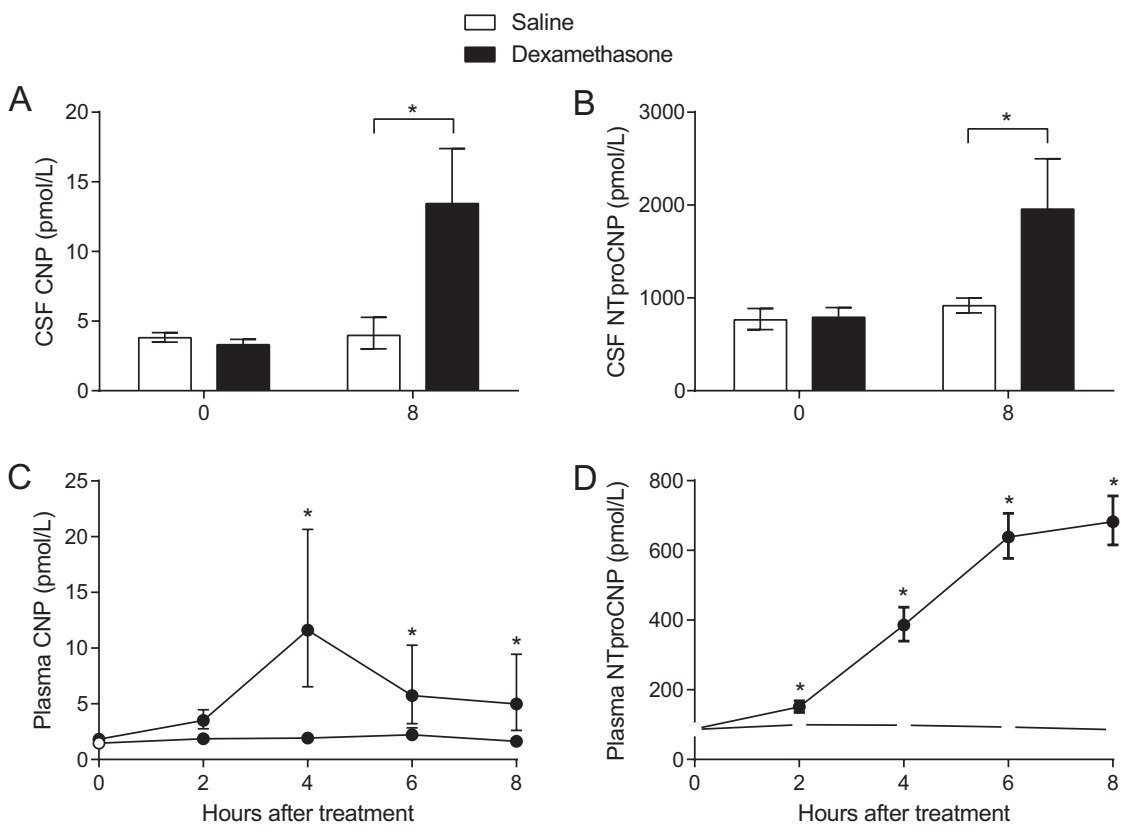

Figure 2

Mean CNP (left) and NTproCNP (right)

concentration in CSF ( $\mathrm{A}$ and $\mathrm{B}$ ) and plasma ( $\mathrm{C}$ and D) of sheep treated with saline solution (open bars/circles) or dexamethasone (closed bars/ circles). Data are presented as geometric means. In CSF, $n=6$ (saline) and $n=7$ (dexamethasone) per group at $0 \mathrm{~h}, n=5$ per group at $8 \mathrm{~h}$. In plasma, $n=7$ per group. *Significant difference between groups, $P<0.05$. 

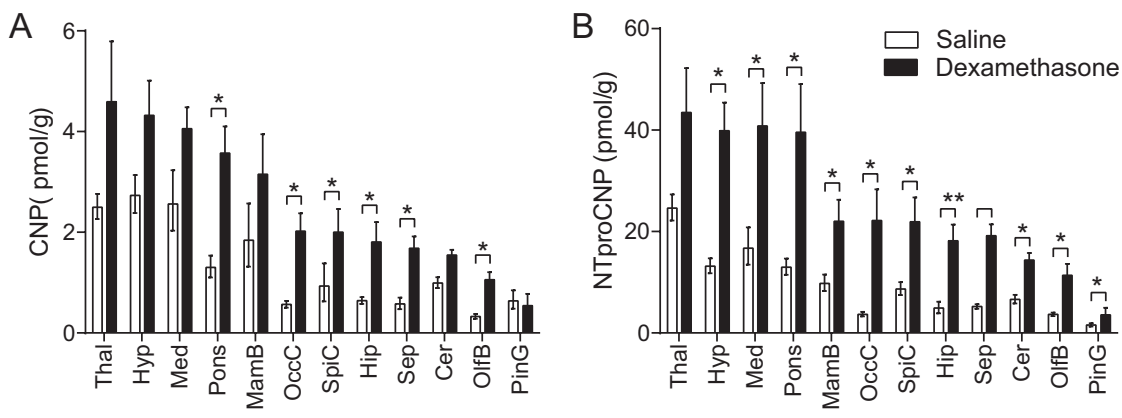

\begin{abstract}
Figure 3
Mean concentration (wet weight basis) of CNP (left panels) and NTCNP (right panels) in brain ( $A$ and $B$ ) and pituitary gland ( $C$ and $D$ ) tissues in saline- (open bars) and dexamethasone-treated sheep (filled bars) $8 \mathrm{~h}$ following treatment. Data are presented as geometric means, $n=7$ per group. *Significant difference between groups, $P<0.05$ Tissue regions are abbreviated to the following: AntP (anterior pituitary gland), PosP (posterior pituitary gland), Thal (thalamus), Hyp (hypothalamus), Med (medulla oblongata), Pons (Pons), MamB (mammillary body), OccC (occipital cortex), SpiC (spinal cord), Hip (hippocampus), Sep (septum), Cer (cerebellum), OlfB (olfactory bulb), PinG (pineal gland).
\end{abstract}

there were significant increments in CNP concentration following dexamethasone in 6 of the 14 selected tissues and those for NTproCNP were significant in 11 of these tissues. The relative abundance of both peptides across brain tissues from controls was largely preserved in tissues extracted from dexamethasone-treated animals. Again, responses in pituitary tissues differed. Neither CNP nor NTproCNP abundance in the posterior lobe was affected by dexamethasone (Fig. 3C and D). NTproCNP levels in the anterior pituitary lobe were increased after dexamethasone (Fig. 3D); however, this was not significant, and in contrast to brain tissues, CNP concentration was unaffected. Considering all 14 tissues, the percentage difference (dexamethasone vs control) in CNP concentration was significantly greater in tissues with relatively low abundance $(r=0.64, P<0.05$, Supplementary Fig. 2). A similar inverse relation was observed for NTproCNP $(r=0.54, P<0.05)$.

Concentrations of the 2 peptides in control sheep were highly correlated in brain $(r=0.68, P<0.0001)$ and pituitary gland $(r=0.81, P<0.05)$, and even more so after dexamethasone: $(r=0.80$ and 0.88 , respectively, $P<0.0001$ for both). However, as shown in Supplementary Fig. 3, across all studies the concentration ratio of NTproCNP to CNP in both pituitary lobes was close to unity (1:1), much lower than found in brain tissues (5:1-10:1).

\section{CNP-related gene expression}

NPPC, NPR2 and NPR3 gene expression levels in selected tissues from saline- and dexamethasone-treated sheep are shown in Fig. 4. NPPC expression levels were upregulated by dexamethasone $(P<0.001)$ in 5 of the 7 tissues examined: anterior pituitary, posterior pituitary, hypothalamus, hippocampus and pons. No significant change in NPPC expression was found in occipital cortex or olfactory bulb tissue. Except for the downregulation of NPR2 in hypothalamic tissue following treatment with dexamethasone $(P<0.05)$, changes in NPR2 and NPR3 gene expression in the other tissues after dexamethasone were not significant (Fig. 4). Despite markedly lower NTCNP:CNP ratios in the anterior and posterior pituitary gland, NPR3 expression in these tissues did not differ from that in the other regions examined here.

\section{Specificity of CNP responses}

Whether natriuretic peptide responses to dexamethasone are specific to CNP was addressed by measuring the concentration of ANP and BNP in samples obtained in Study 2. As shown in Fig. 5, whereas small fluctuations in plasma ANP and BNP concentration were observed after saline or dexamethasone, the mean values for either hormone after dexamethasone $(0.25 \mathrm{mg} / \mathrm{kg}$ live weight) did not differ from those following the saline treatment. Both ANP and BNP were undetectable in CSF, including samples obtained after dexamethasone. In brain tissue extracts, ANP was undetectable in 29 of 42 samples examined. In 3 tissues where ANP was detectable (olfactory bulb, thalamus and pons) concentrations after dexamethasone (mean $0.84 \pm 0.43 \mathrm{pmol} / \mathrm{L}, n=6$ ) were low and did not differ from control sheep (mean $0.72 \pm 0.30$,

Published by Bioscientifica Ltd 

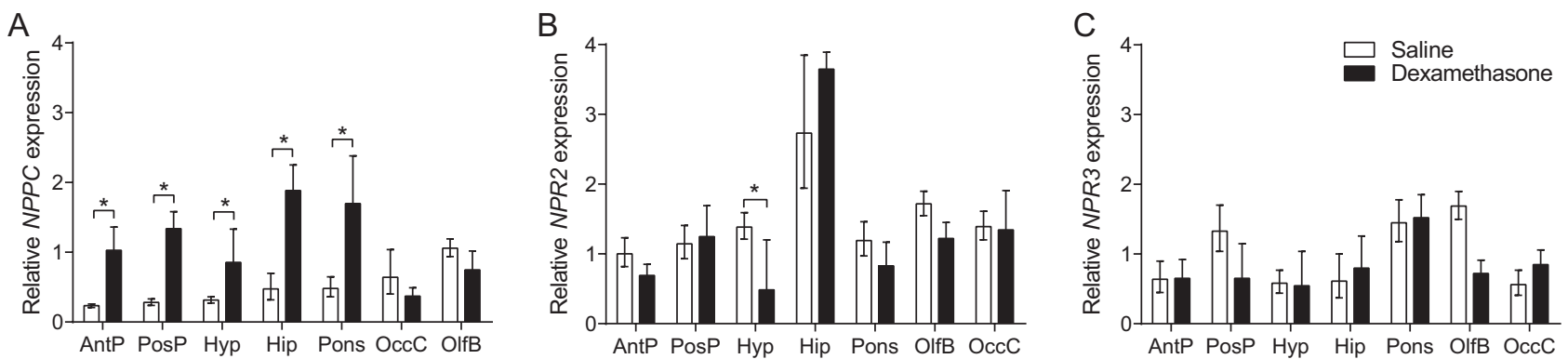

Figure 4

Relative gene expression of (A) NPPC, (B) NPR2 and (C) NPR3 in tissues from brain and pituitary gland of sheep obtained at $8 \mathrm{~h}$ following treatment with IV saline solution (open bars) or a single IV dose of dexamethasone (closed bars). Data are presented as geometric means, $n=7$ per group. *Significant difference between groups, $P<0.05$. See Fig. 3 for abbreviations.

$n=7)$. BNP was undetectable in 37 of 39 samples analysed. Gene expression levels of NPPA, NPPB and NPR1 did not differ between dexamethasone- and saline-treated sheep ( $P=0.461,0.702$ and 0.22 , respectively, $n=6$ /group) in tissue sampled from the anterior or posterior pituitary gland, hypothalamus, hippocampus, pons, occipital cortex and olfactory bulb (Fig. 5).

\section{Discussion}

CNP is the most abundant of the natriuretic peptides present in CNS tissues (Ueda et al. 1991, Kaneko et al. 1993). Whereas its role in the early development and maturation of cerebral neurons (Müller et al. 2009), and in axonal branching of sensory neurons entering the CNS (Zhao \& Ma 2009) is well defined, factors regulating CNP production within the brain and related tissues of adults in vivo have not been studied. Here we show that a single IV bolus injection of dexamethasone abruptly increases plasma and CSF concentrations of CNP peptides selectively and dose dependently. These changes are associated with marked increases in peptide concentrations in a wide range of CNS tissues, and upregulation of NPPC mRNA expression in 5 of the 7 cranial tissues examined here. Collectively these novel findings suggest that CNP may mediate some of the acute effects of stress on brain function, which now warrants further study.
A
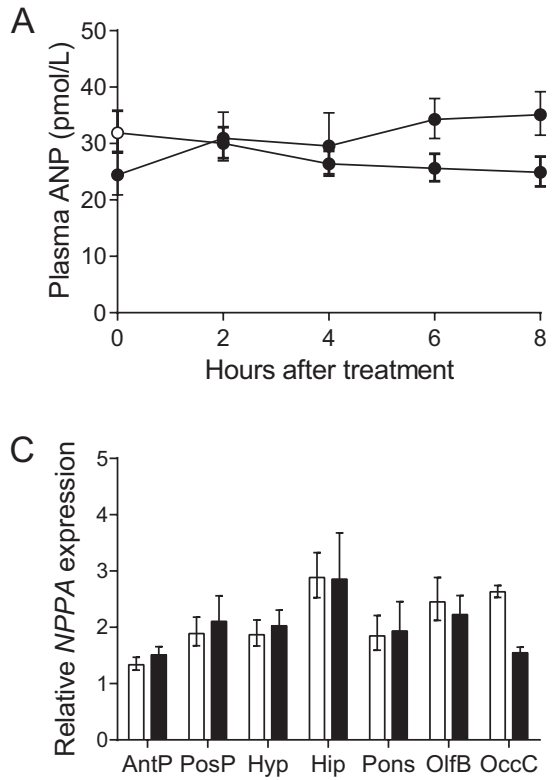

$\mathrm{B}$
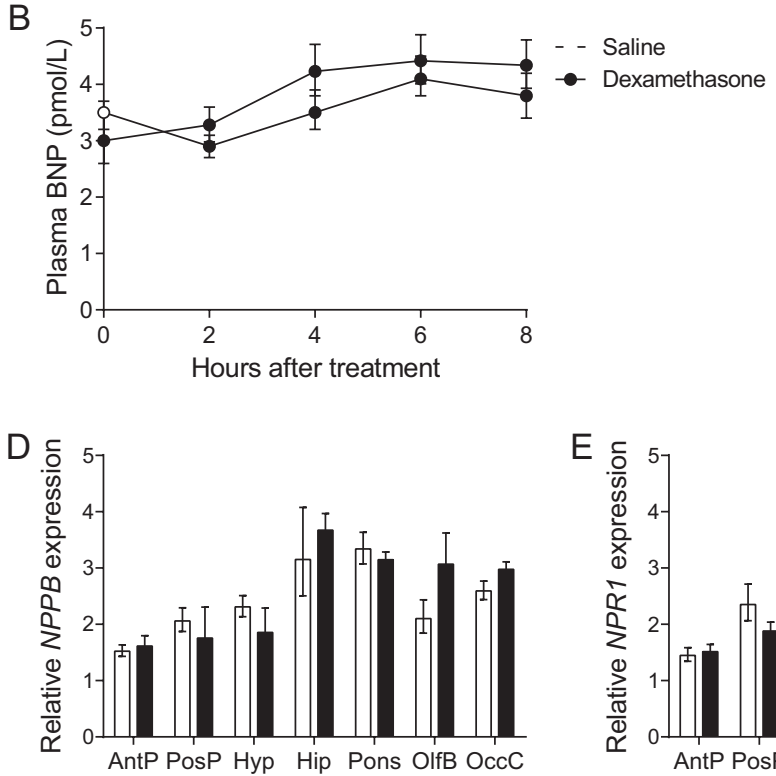

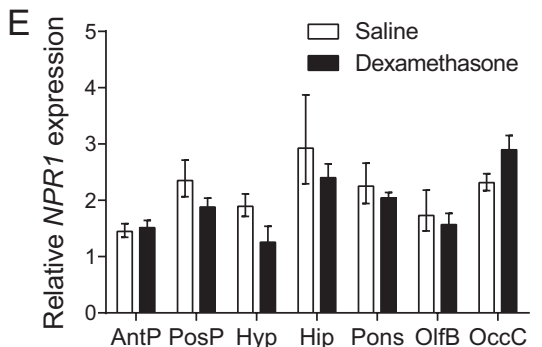

Figure 5

Mean (A) plasma ANP concentration, (B) plasma BNP concentration and mean relative gene expression of (C) NPPA, (D) NPPB and (E) NPR1 in brain and pituitary tissues in sheep treated with saline solution (open circles/bars) or dexamethasone (filled circles/bars). Data are presented as geometric means, $n=7$ per group. See Fig. 3 for abbreviations. 
As part of physiological studies examining fluctuations of CNP peptides in CSF drawn from conscious adult sheep, we found that doses of dexamethasone (at levels that can reduce plasma concentrations of CNP peptides in lambs when administered for several days (Prickett et al. 2009)) actually raise concentrations of CNP in CSF during the first $12 \mathrm{~h}$. We now show that in contrast to relatively unchanged levels that persist after administration of saline, a single IV bolus injection of dexamethasone induces a prompt increase in CNP and NTproCNP concentrations in both plasma and CSF. Peptide concentrations of ANP and BNP were unaffected, and levels of gene expression of NPPA and $N P P B$ in brain and pituitary tissue did not differ between dexamethasone- and saline-treated animals. As noted in humans (Schouten et al. 2011), in the absence of interventions (i.e. saline-treated animals here), concentrations of CNP and NTproCNP were much higher in CSF than in time-matched samples of plasma. Lack of any significant correlation between levels in the two circulations suggests independent regulation and little, if any, exchange across the blood-brain barrier (BBB). After dexamethasone, onset of the response in CNP peptide levels occurred earlier in plasma (within $4 \mathrm{~h}$ ) was dose dependent and of shorter duration than was observed in CSF. Presumably delayed entry of dexamethasone to the CNS (Balis et al. 1987), diffusion and bulk flow of CNP peptides from extracellular fluid to CSF (Leng \& Ludwig 2008) and slower clearance of CNP peptides in CSF (particularly NTproCNP) are the basis of these temporal differences. Sustained elevations of NTproCNP in CSF $16 \mathrm{~h}$ after dexamethasone, when plasma levels had returned to baseline, suggest that any increase in permeability of the BBB by CNP (Bohara et al. 2014) is minimal in this experimental setting.

In order to examine likely sources of the response of CNP peptides in CSF, we measured their relative abundance in 12 selected tissues within the CNS $8 \mathrm{~h}$ after saline or dexamethasone $(0.25 \mathrm{mg} / \mathrm{kg}$ live weight); a dose which strongly stimulated plasma and CSF CNP peptides in these same sheep when compared with the control study. In controls, the relative abundance of CNP peptides in CNS tissues was similar to that previously reported in adult sheep (Pemberton et al. 2002), rodents (Jankowski et al. 2004) and humans (Komatsu et al. 1991, Totsune et al. 1994). Highest concentrations were found in tissue sampled from thalamus, hypothalamus, mammillary body and medulla oblongata. Overall, concentrations of the two peptides were highly correlated in brain and pituitary gland of control sheep, with levels of NTproCNP approximately 5-10 fold those of CNP in brain tissue. Of the 12 CNS tissues examined, the concentration of both peptides was higher after dexamethasone when compared with controls (significantly so in 11 and 6 tissues for NTproCNP and CNP, respectively). Tissues with lower abundance after saline exhibited proportionately higher levels after dexamethasone (Supplementary Fig. 2). This trend was more obvious in the CNP response, possibly reflecting higher rates of secretion (loss to extracellular fluid and CSF) for this peptide, particularly in tissue zones adjacent to cerebral ventricles. Again, after dexamethasone significant associations were observed between CNP and NTproCNP but in 4 tissues (hypothalamus, pineal gland, occipital cortex and medulla oblongata) the ratio of NTproCNP to CNP was significantly increased compared with control values. Presumably higher rates of CNP degradation and/or egress from the neuropil account for these glucocorticoid-induced differences. Viewed in relation to proportionate increases in CSF at $8 \mathrm{~h}$ after dexamethasone $(0.25 \mathrm{mg} / \mathrm{kg}$ live weight $)$ the increase in brain tissue CNP content (2-4 fold) is commensurate with that observed in CSF (3-4 fold) and lends credibility to the possibility that the changed levels in CSF are a consequence of enhanced secretion from tissues within the CNS. Proof that these changes involve increased synthesis of the peptides is provided by the evidence presented here for upregulation of NPPC in the hypothalamus, hippocampus and pons. In contrast, NPPC expression in the occipital cortex and olfactory bulb was not increased by dexamethasone, despite significant increases in both CNP and NTproCNP concentrations in these tissues. This discrepancy may relate to differences in mRNA stability (rapid degradation compared with peptide loss) and/or co-production of inhibitory microRNAs.

Whether longer-term treatment with dexamethasone could sustain the responses we observed here in CNS tissues is unknown but important to resolve, particularly since plasma levels of CNP peptides are suppressed by prolonged dosing with dexamethasone in growing lambs and children (Prickett et al. 2009, 2012a). In the latter studies, contributions of NTproCNP to its plasma concentrations are likely to be sourced from growth plate-proliferating chondrocytes (Prickett et al. 2005, 2012b) (which are depleted by glucocorticoids (Siebler et al. 2002)), so it is not surprising that the temporal responses of CNS tissues to glucocorticoids are likely to vary from those in other body regions. In this context, possible stimulation of CNP by endogenous increases in glucocorticoid secretion also need consideration although previous study showing stable levels of CNP products

Published by Bioscientifica Ltd 
in both plasma and CSF over periods of $24 \mathrm{~h}$ sampling (Wilson et al. 2015) make this unlikely.

Although it is not part of the CNS, and is unprotected by the $\mathrm{BBB}$, the pituitary gland in sheep and humans has an unusually high CNP content (Yandle et al. 1993, Pemberton et al. 2002, Thompson et al. 2009), so its potential to contribute to the amount of CNP in plasma or CSF was an important factor in selecting this organ for closer study. Findings in pituitary tissue differ from those in CNS tissues in several respects. First, in control sheep, the concentration of CNP is much higher in both anterior and posterior lobes than in any of the regions of the CNS reported here. Second, in both lobes, there are equimolar concentrations of CNP and NTproCNP, reducing the ratio of NTproCNP:CNP to unity (1:1) (much lower than that found in CNS tissues (5:1-10:1, Supplementary Fig. 3)). Previous work (Yandle et al. 1993) has also shown that the pituitary processing of proCNP is unique in that pituitary tissue contains predominantly CNP-53, contrasting with the presence of equal amounts of CNP-53 and the smaller peptide CNP-22 in hypothalamic extracts. These findings suggest that under physiological conditions different functions are subserved in the pituitary gland, with less degradation and reduced processing being consistent with accumulation and storage. Thirdly, although NPPC expression in both lobes is significantly upregulated after dexamethasone, abundance of peptides was not changed. Together these unexpected findings raise the possibility that both peptides are actively secreted from the pituitary gland into the systemic circulation in response to dexamethasone, and thus could make significant contributions to the responses recorded in plasma after IV administered dexamethasone. If so, a disproportionate amount of CNP-53 would be expected to appear in the systemic circulation. More recent studies in our laboratory confirm this and show that the profile of high-molecular-weight immunoreactive CNP forms in plasma closely reflects the profile found in anterior pituitary tissue extracts (MO Wilson, GK Barrell, TCR Prickett \& EA Espiner, unpublished observations). Others have shown that CNP in anterior pituitary tissue appears to be associated with gonadotrophic cells (McArdle et al. 1994, Thompson et al. 2009) as well as other cell lineages in human pituitary adenomas (Thompson et al. 2012). Reports that acute stress or glucocorticoid administration stimulates gonadotrophin secretion in some settings (Maeda \& Tsukamura 2006) may be relevant in this context. Although we have not found evidence of a CNP arterio-venous concentration gradient across the pituitary gland in samples of plasma drawn from the inferior petrosal vein in human subjects with Cushing's disease (TCR Prickett \& EA Espiner, unpublished observations), further study of the acute effect of glucocorticoids on pituitary secretion of CNP peptides is warranted.

Our study was not designed to address either the origins or actions of CNP at the cellular level but these questions become highly relevant in light of the present findings, and of the manifold effects of glucocorticoids on brain function (Wolkowitz et al. 2009). Notably, CNP responses in CSF were observed after a dexamethasone dose of $0.125 \mathrm{mg} / \mathrm{kg}$ live weight, which corresponds to the therapeutic range for adult humans. The wide array of glucocorticoid-responsive CNS tissues identified here suggests that commonalities (such as capillary networks (Vigne \& Frelin 1992) or glial tissues (Parpura \& Zorec 2010), all of which are recognised sites of CNP production) are likely to be involved. One possible action of dexamethasone, increasing the CNP mRNA response to shear stress in brain capillaries (Zhang et al. 1999), might account for the present results. In cultured murine cerebral cortex neurons, activation of voltagesensitive calcium channels during potassium-induced depolarisation strongly upregulates NPPC expression over a $6 \mathrm{~h}$ period (Kim et al. 2010). Since glucocorticoids specifically enhance L-type calcium channel amplitude in a variety of neurons sourced from brain tissues (Joëls \& Karst 2012), the glucocorticoid-induced increases in CNP we observed may have resulted from such membranelevel events (Wolkowitz et al. 2009). Responses from astrocytes or microglia (ubiquitous in CNS tissues and an important source of natriuretic peptides, including CNP (Deschepper 1998)) may also have contributed to these findings. Of note, dexamethasone elicits a dose-dependent CNP response from cells of monocyte/macrophage lineage (Kubo et al. 2001) which, within the BBB, constitute the microglia. To our knowledge, no glucocorticoid response element has been identified in the CNP gene in any species. Interestingly, glucocorticoids act directly and specifically to increase ANP gene transcription in rodent cardiomyocytes (Gardner et al. 1988) and other tissues (Gardner et al. 1986) yet dexamethasone did not alter NPPA (or NPPB) expression in any of the central tissues studied here, and we found no evidence that ANP or BNP concentration is affected by dexamethasone in either the systemic circulation or CNS tissues. In further support of a CNP-specific action of dexamethasone in central tissues, the expression of the ANP and BNP receptor, NPR1, was also unaffected. Concerning possible actions of CNP in glial tissues, there is a strong body of evidence

Published by Bioscientifica Ltd. 
that cGMP, a downstream mediator of CNP activity and more responsive to CNP than either ANP or BNP (Deschepper \& Picard 1994), regulates several crucial intercellular actions including $\mathrm{Na}^{+} / \mathrm{H}^{+}$exchangers, neurotransmitter re-uptake, gap junctions, cell $\mathrm{pH}$ and brain cell water content (Kim et al. 2010). In this context, it is important to note that dexamethasone mitigates cerebral glioma tumour oedema, a cell type highly responsive to CNP (Eguchi et al. 1992, Wu et al. 2017). Conceivably, this well-described pharmacological action of dexamethasone is mediated at least in part by CNP which could have therapeutic implications now that CNP agonists are available for use in humans.

\section{Supplementary data}

This is linked to the online version of the paper at http://dx.doi.org/10.1530/ JOE-17-0148.

\section{Declaration of interest}

E A E is a consultant for BioMarin Pharmaceutical. The authors have no conflicts of interest to disclose.

\section{Funding}

$\mathrm{M} O \mathrm{~W}$ has received financial support from a William Machin Doctoral Scholarship. This work did not receive any specific grant but was funded by basal operational funding of Lincoln University and the Department of Medicine, University of Otago, Christchurch - the latter of which is supported by the Christchurch Heart Institute. Gene expression analysis work was hosted by the School of Medicine at Deakin University, Geelong, with additional financial support for this supplied by basal operational funding at Lincoln University.

\section{Acknowledgements}

The authors thank Martin Wellby, Katharina Russell, Amy Smaill and James Meyer at Lincoln University for technical assistance with the animal procedures.

\section{References}

Abdelalim EM \& Tooyama I 2011 Mapping of NPR-B immunoreactivity in the brainstem of Macaca fascicularis. Brain Structure and Function 216 387-402. (doi:10.1007/s00429-011-0313-1)

Balis FM, Lester CM, Chrousos GP, Heideman RL \& Poplack DG 1987 Differences in cerebrospinal fluid penetration of corticosteroids: possible relationship to the prevention of meningeal leukemia. Journal of Clinical Oncology 5 202-207. (doi:10.1200/JCO.1987.5.2.202)

Bohara M, Kambe Y, Nagayama T, Tokimura H, Arita K \& Miyat A 2014 C-type natriuretic peptide modulates permeability of the blood-brain barrier. Journal of Cerebral Blood Flow and Metabolism 34 589-596. (doi:10.1038/jcbfm.2013.234)
Decker JM, Wójtowicz AM, Bartsch JC, Liotta A, Braunewell KH, Heinemann U \& Behrens CJ 2010 C-type natriuretic peptide modulates bidirectional plasticity in hippocampal area CA1 in vitro. Neuroscience 169 627-639. (doi:10.1016/j.neuroscience.2010.04.064)

Deschepper CF 1998 Peptide receptors on astrocytes. Frontiers in Neuroendocrinology 19 20-46. (doi:10.1006/frne.1997.0161)

Deschepper CF \& Picard S 1994 Effects of C-type natriuretic peptide on rat astrocytes: regional differences and characterization of receptors. Journal of Neurochemistry 62 1974-1982. (doi:10.1046/j.14714159.1994.62051974.x)

Eguchi S, Hirata Y, Imai T, Kanno K, Ohta K, Emori T \& Marumo F 1992 Effects of three distinct natriuretic peptides on receptor binding and guanylate cyclase activities in rat glioma cells. European Journal of Pharmacology 225 79-82. (doi:10.1016/0922-4106(92)90043-U)

Gardner DG, Hane S, Trachewsky D, Schenk D \& Baxter JD 1986 Atrialnatriuretic-peptide messenger-RNA is regulated by glucocorticoids in vivo. Biochemical and Biophysical Research Communications 139 1047-1054. (doi:10.1016/S0006-291X(86)80283-2)

Gardner DG, Gertz BJ, Deschepper CF \& Kim DY 1988 Gene for the rat atrial natriuretic peptide is regulated by glucocorticoids in vitro. Journal of Clinical Investigation 82 1275-1281. (doi:10.1172/ JCI113726)

Herman JP, Dolgas CM, Rucker D \& Langub MC Jr 1996 Localization of natriuretic peptide-activated guanylate cyclase mRNAs in the rat brain. Journal of Comparative Neurology 369 165-187. (doi:10.1002/ (SICI)1096-9861(19960527)369:2<165::AID-CNE1>3.0.CO;2-1)

Jankowski M, Reis AM, Wang D \& Gutkowska J 2004 Postnatal ontogeny of natriuretic peptide systems in the rat hypothalamus. Developmental Brain Research 152 39-46. (doi:10.1016/j.devbrainres.2004.05.011)

Joëls M \& Karst H 2012 Corticosteroid effects on calcium signalling in limbic neurons. Cell Calcium 51 277-283. (doi:10.1016/j.ceca.2011.11.002)

Kaneko T, Shirakami G, Nakao K, Nagata I, Nakagawa O, Hama N, Suga S, Miyamoto S, Kubo H, Hirai O, et al. 1993 C-type natriuretic peptide (CNP) is the major natriuretic peptide in human cerebrospinal fluid. Brain Research 612 104-109. (doi:10.1016/0006-8993(93)91649-D)

Kim TK, Hemberg M, Gray JM, Costa AM, Bear DM, Wu J, Harmin DA, Laptewicz M, Barbara-Haley K, Kuersten S, et al. 2010 Widespread transcription at neuronal activity-regulated enhancers. Nature 465 182-187. (doi:10.1038/nature09033)

Komatsu Y, Nakao K, Suga S, Ogawa Y, Mukoyama M, Arai H, Shirakami G, Hosoda K, Nakagawa O, Hama N, et al. 1991 C-type natriuretic peptide (CNP) in rats and humans. Endocrinology 129 1104-1106. (doi:10.1210/endo-129-2-1104)

Kubo A, Isumi Y, Ishizaka Y, Tomoda Y, Kangawa K, Dohi K, Matsuo H \& Minamino N 2001 C-type natriuretic peptide is synthesized and secreted from leukemia cell lines, peripheral blood cells, and peritoneal macrophages. Experimental Hematology 29 609-615. (doi:10.1016/S0301-472X(01)00625-7)

Langub M, Watson M \& Herman J 1995 Distribution of natriuretic peptide precursor messenger-RNAs in the rat brain. Journal of Comparative Neurology 356 183-199. (doi:10.1002/cne.903560205)

Leng G \& Ludwig M 2008 Neurotransmitters and peptides: whispered secrets and public announcements. Journal of Physiology $\mathbf{5 8 6}$ 5625-5632. (doi:10.1113/jphysiol.2008.159103)

Maeda K \& Tsukamura H 2006 The impact of stress on reproduction: are glucocorticoids inhibitory or protective to gonadotropin secretion? Endocrinology 147 1085-1086. (doi:10.1210/en.2005-1523)

McArdle CA, Olcese J, Schmidt C, Poch A, Kratzmeier M \& Middenorff R 1994 C-type natriuretic peptide (CNP) in the pituitary: is CNP an autocrine regulator of gonadotropes? Endocrinology 135 2794-2801. (doi:10.1210/endo.135.6.7988473)

Minamino N, Makino Y, Tateyama H, Kangawa K \& Hisayiki M 1991 Characterization of immunoreactive human C-type natriuretic peptide in brain and heart. Biochemical and Biophysical Research Communications 179 535-542. (doi:10.1016/0006291X(91)91404-Z) 
Müller D, Hida B, Guidone G, Speth R, Michurina T, Enikolopov G \& Middendorff R 2009 Expression of guanylyl cyclase (GC)-A and GC-B during brain development: evidence for a role of GC-B in perinatal neurogenesis. Endocrinology 150 5520-5529. (doi:10.1210/en.2009-0490)

Parpura V \& Zorec R 2010 Gliotransmission: exocytotic release from astrocytes. Brain Research Reviews 63 83-92. (doi:10.1016/j. brainresrev.2009.11.008)

Pemberton CJ, Yandle TG, Charles CJ, Rademaker MT, Aitken GD \& Espiner EA 1997 Ovine brain natriuretic peptide in cardiac tissues and plasma: effects of cardiac hypertrophy and heart failure on tissue concentrations and molecular forms. Journal of Endocrinology 155 541-550. (doi:10.1677/joe.0.1550541)

Pemberton C, Yandle T \& Espiner E 2002 Immunoreactive forms of natriuretic peptides in ovine brain: response to heart failure. Peptides 23 2235-2244. (doi:10.1016/S0196-9781(02)00263-2)

Prickett TCR, Lynn AM, Barrell GK, Darlow BA, Cameron VA, Espiner EA, Richards AM \& Yandle TG 2005 Amino-terminal proCNP: putative marker of cartilage activity in postnatal growth. Pediatric Research $\mathbf{5 8}$ 334-340. (doi:10.1203/01.PDR.0000169964.66260.4B)

Prickett TCR, Charles CJ, Yandle TG, Richards AM \& Espiner EA 2009 Skeletal contributions to plasma CNP forms: evidence from regional sampling in growing lambs. Peptides 30 2343-2347. (doi:10.1016/j. peptides.2009.07.023)

Prickett TCR, Lyver A, Wilson R, Espiner EA \& Sulliyan MJ 2012a C-type natriuretic peptide: a novel biomarker of steroid induced bone toxicity in children with acute lymphoblastic leukemia (ALL). Peptides 36 54-59. (doi:10.1016/j.peptides.2012.04.017)

Prickett TCR, Bothwell JC, Yandle TG, Richards AM \& Espiner EA $2012 b$ Pharmacodynamic responses of plasma and tissue C-type natriuretic peptide to $\mathrm{GH}$ : correlation with linear growth in GH-deficient rats. Journal of Endocrinology 212 217-225. (doi:10.1530/JOE-11-0387)

Schouten B, Prickett TCR, Hooper A, Hooper G, Yandle T, Richards A \& Espiner E 2011 Central and peripheral forms of C-type natriuretic peptide (CNP): evidence for differential regulation in plasma and cerebrospinal fluid. Peptides 32 797-804. (doi:10.1016/j. peptides.2011.01.013)

Siebler T, Robson H, Shalet SM \& Williams GR 2002 Dexamethasone inhibits and thyroid hormone promotes differentiation of mouse chondrogenic ATDC5 cells. Bone 31 457-464. (doi:10.1016/S87563282(02)00855-4)

Thompson IR, Chand AN, Jonas KC, Burrin JM, Steinhelper ME, WheelerJones CP, McArdle CA \& Fowkes RC 2009 Molecular characterisation and functional interrogation of a local natriuretic peptide system in rodent pituitaries, $\alpha \mathrm{T} 3-1$ and L $\beta \mathrm{T} 2$ gonadotroph cells. Journal of Endocrinology 203 215-229. (doi:10.1677/JOE-09-0189)

Thompson I, Chand A, King P, Ansorge O, Karavitaki N, Jones C, Rahmutula D, Gardner D, Zivkovic V, Wheeler-Jones C, et al. 2012
Expression of guanylyl cyclase-B (GC-B/NPR2) receptors in normal human fetal pituitaries and human pituitary adenomas implicates a role for C-type natriuretic peptide. Endocrine-Related Cancer 19 497-508. (doi:10.1530/ERC-12-0129)

Totsune K, Takahashi K, Ohneda M, Itoi K, Murakami O \& Mouri T $1994 \mathrm{C}$-type natriuretic peptide in the human central nervous system: distribution and molecular form. Peptides 15 37-40. (doi:10.1016/0196-9781(94)90167-8)

Ueda S, Minamino N, Aburaya M, Kangawa K, Matsukura S \& Matsuo H 1991 Distribution and characterization of immunoreactive porcine C-type natriuretic peptide. Biochemical and Biophysical Research Communications 175 759-767. (doi:10.1016/0006291X(91)91631-L)

Vigne P \& Frelin C 1992 C-type natriuretic peptide is a potent activator of guanylate cyclase in endothelial cells from brain microvessels. Biochemical and Biophysical Research Communications 183 640-644. (doi:10.1016/0006-291X(92)90530-X)

Wilson MO \& Barrell GK 2015 Modification of a method for cannulation of the cisterna magna in sheep to enable chronic collection of cerebrospinal fluid. Laboratory Animals 49 85-87. (doi:10.1177/0023677214557170)

Wilson MO, Barrell GK, Prickett TCR \& Espiner EA 2015 Sustained increases in plasma C-type natriuretic peptides fail to increase concentrations in cerebrospinal fluid: evidence from pregnant sheep. Peptides 69 103-108. (doi:10.1016/j.peptides.2015.04.016)

Wolkowitz OM, Burke H, Epel ES \& Reus VI 2009 Glucocorticoids. Mood, memory, and mechanisms. Annals of the New York Academy of Sciences 1179 19-40. (doi:10.1111/j.1749-6632.2009.04980.x)

Wu J, Mu L, Bu Y, Liu L, Yan Y, Hu Y, Bai J, Zhang J, Lu W \& Lu W 2017 C-type natriuretic peptide-modified lipid vesicles: fabrication and use for the treatment of brain glioma. Oncotarget 8 40906-40921. (doi:10.18632/oncotarget.16641)

Yandle TG, Espiner EA, Nicholls MG \& Duff H 1986 Radioimmunoassay and characterization of atrial natriuretic peptide in human plasma. Journal of Clinical Endocrinology and Metabolism 63 72-79. (doi:10.1210/jcem-63-1-72)

Yandle T, Fisher S, Charles C, Espiner E \& Richards A 1993 The ovine hypothalamus and pituitary have markedly different distributions of C-type natriuretic peptide forms. Peptides 14 713-716. (doi:10.1016/0196-9781(93)90102-M)

Zhang Z, Xiao Z \& Diamond SL 1999 Shear stress induction of C-type natriuretic peptide (CNP) in endothelial cells is independent of NP autocrine signalling. Annals of Biomedical Engineering 27 419-456. (doi:10.1114/1.203)

Zhao Z \& Ma L 2009 Regulation of axonal development by natriuretic peptide hormones. PNAS 106 18016-18021. (doi:10.1073/ pnas.0906880106)

Received in final form 11 June 2017

Accepted 4 July 2017

Accepted Preprint published online 4 July 2017 http://joe.endocrinology-journals.org

DOI: $10.1530 / \mathrm{JOE}-17-0148$ (c) 2017 Society for Endocrinology Printed in Great Britain
Published by Bioscientifica Ltd 